Article

\title{
Estimation of Heat Source Model's Parameters for GMAW with Non-linear Global Optimization-Part I: Application of Multi-island Genetic Algorithm
}

\author{
Changmin Pyo, Jisun Kim and Jaewoong Kim * \\ Smart Manufacturing Process R\&D Group, Korea Institute of Industrial Technology, Gwangju 61012, Korea; \\ changmin@kitech.re.kr (C.P.); kimjisun@kitech.re.kr (J.K.) \\ * Correspondence: kjw0607@kitech.re.kr; Tel.: +82-62-600-6480
}

Received: 10 June 2020; Accepted: 1 July 2020; Published: 3 July 2020

check for updates

\begin{abstract}
Estimating the thermo-elasto-plastic deformation by arc welding through finite element analysis has been used in various industrial fields. The Goldak heat source model is one of the most important and widely used models in finite element analysis, and its parameters are estimated based on the results of previous studies and tests. Part I of this study focused on the adequate heat source model, and the study for the welding deformation with the moving heat source will be done on the latter research. This study used the parameters of Goldak's heat source model, weld efficiency, and the location of the heat source as design variables, and defined the Heat Affected Zone (HAZ) boundary line of Bead on Plate (BOP) welding as the target. BOP welding was performed using SS400 plates, the HAZ boundary line was determined based on examining the shape of the cross-section, and the optimization condition was that temperature inside the boundary line exceeded $727^{\circ} \mathrm{C}$ while the temperature outside the line did not exceed $727^{\circ} \mathrm{C}$ during the welding process. During this process, a multi-island genetic algorithm (non-linear global optimization method) was used to obtain the optimal results out of 1000 candidate groups, in which the HAZ boundary was similar to the experimental results. Applying a global optimization algorithm to determine the parameters of the most important heat source model to analyze welding deformation is significant, and this may be applied in various industrial fields that use welding including shipbuilding, aviation, and machinery industries.
\end{abstract}

Keywords: Goldak heat source model; multi-island genetic algorithm; GMAW

\section{Introduction}

Welding is one of the most commonly used processing techniques in the machinery, shipbuilding, and aviation industries. Welding is a process of joining the same or dissimilar metals after raising the temperature to the melting point by using a heat source. Some of the most common welding methods are Shield Metal Arc Welding (SMAW) [1], Flux Cored Arc Welding (FCAW) [2], and Submerged Arc Welding (SAW) [3], and Gas Metal Arc Welding (GMAW) [4] is the most widely used method in most industrial fields.

Welding is a process of thermo-elasto-plastic deformation, resulting in permanent deformation. Experimental methods are often used in the field to control deformation, and computer simulations are also used to predict and respond to deformation [5-7]. Estimating the heat source is critical in welding analysis though computer simulations and many studies have been conducted on this subject. Rosenthal [8] estimated the heat source as a 1-point source, but errors occurred because the size of the heat source was infinite and the temperature-dependent material properties were not considered.

Distributed heat source models were developed such as the Gaussian heat source model and the double-ellipsoidal heat source model to overcome this problem. The Goldak model is the most 
well-known double-ellipsoidal heat source model [9]. Figure 1 shows the heat distribution of the Goldak model according to Equations (1) and (2) below.

$$
\begin{gathered}
q_{f}(x, y, z, t)=\exp \left(-3\left(\frac{\left(z-v t-z_{0}\right)^{2}}{a_{f}{ }^{2}}+\frac{y^{2}}{c^{2}}+\frac{x^{2}}{b}\right)\right) \\
q_{r}(x, y, z, t)=\frac{6 \sqrt{3} f_{r} Q}{a_{r} b c \pi} \exp \left(-3\left(\frac{\left(z-v t-z_{0}\right)^{2}}{a_{f}+a_{r}}+\frac{y^{2}}{c^{2}}+\frac{x^{2}}{b^{2}}\right)\right) \\
f_{r}=\frac{2 a_{f}}{a_{f}+a_{r}} \quad\left(f_{f}: \text { Fraction of heat deposited at the front ellipsoid }\right)
\end{gathered}
$$

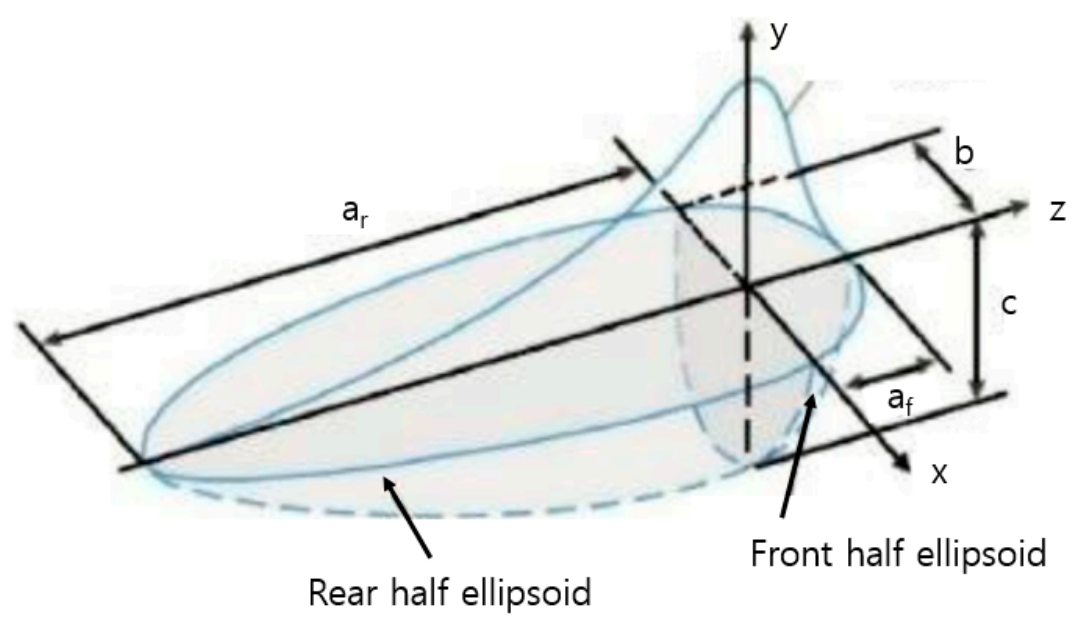

Figure 1. Heat distribution of Goldak model [9].

$\mathrm{v}$-Velocity of heat source

$$
\mathrm{Q}=\mu \mathrm{VI}
$$

Q-Effective heat energy (W);

$\mu$-Weld efficiency;

V-Voltage (V);

I-Current (A).

The main parameters of the Goldak model were not fixed but varied depending on the welding conditions and the environment, and the appropriate values were obtained through a parametric study using a combination of several variables [10-14]. Lee estimated the main parameters of the Goldak heat source model by observing the cross-section after welding tests [10], Tchoumi used a symmetric source model to analyze the heat source for TIG welding using stainless steel 316L and applied the response surface minimization method to derive the parameters based on factorial DOE (Design of Experiments) results [11]. Chujutalli used FEM (Finite Element Method) to find the Goldak model's parameters by setting the peak temperature as the target and derived the values through a parametric study [12]. Podder estimated the main parameters by observing the cross-section after welding tests [13]. In addition to arc welding, studies are also conducted on estimating the heat source shape for analyzing thermal deformation in laser welding, and Kim performed a study to estimate the parameters by assuming the keyhole as a Gaussian distribution [14].

The Goldak model has at least four variables $\left(a_{f}, a_{r}, b\right.$, and $\left.c\right)$, and if each variable is composed of five candidates, 625 combinations are configured, which is inefficient. 
This study performed a more efficient parametric study by using a global optimization method instead of a full factorial method, which was widely used in the past. Adaptive simulated annealing and genetic optimization algorithm are the most well-known global optimization methods, and this study used the Multi-Island Genetic Optimization Algorithm (MIGA), which is a verified method widely used in welding and other research areas [15-18].

Hu used MIGA for the optimal design of satellite separation systems [15], and Lin used MIGA as a way to optimize energy efficiency in building design [16]. Wang used MIGA as a method to predict the lifetime of lithium-ion batteries [17], and Zhao used it to optimize the design of aircraft airfoils [18].

This study implemented simulations conducting BOP (Bead on Plate) tests on mild steel, using Abaqus (Dassault Systems) as the FEM software for the simulations and Fortran to implement the moving heat source. The performance of the software above has been verified and is widely used in research using welding simulations [19-22].

Isight (Dassault Systems), which is widely used to analyze various structures, was used to implement the genetic optimization algorithm [23-25]. Wang used Isight to optimize the design of compressor rotors [23], and Hahn used it for the optimal design of turbine blades [24].

The target of optimization was to match the HAZ (Heat Affected Zone) of the experiment with FEM. To achieve this, the HAZ was defined as the section that exceeds $727^{\circ} \mathrm{C}$ during the welding process, and the HAZ line was coordinated and used for FEM analysis [26].

This study set the parameters of the Goldak heat source model, weld efficiency, and the location of the heat source as the variables, and identified the parameters when reaching the target values. Although previous studies fixed the heat source point on top of the bead [12,27], the concentration of the heat source occurs in the welding wire in actual welding. Per this configuration, it is difficult to represent the actual phenomenon by fixing the heat source point to the top of the bead in FEM modeling. Therefore, this study defined the heat source point as a variable, which is defined as shown in Figure 2.

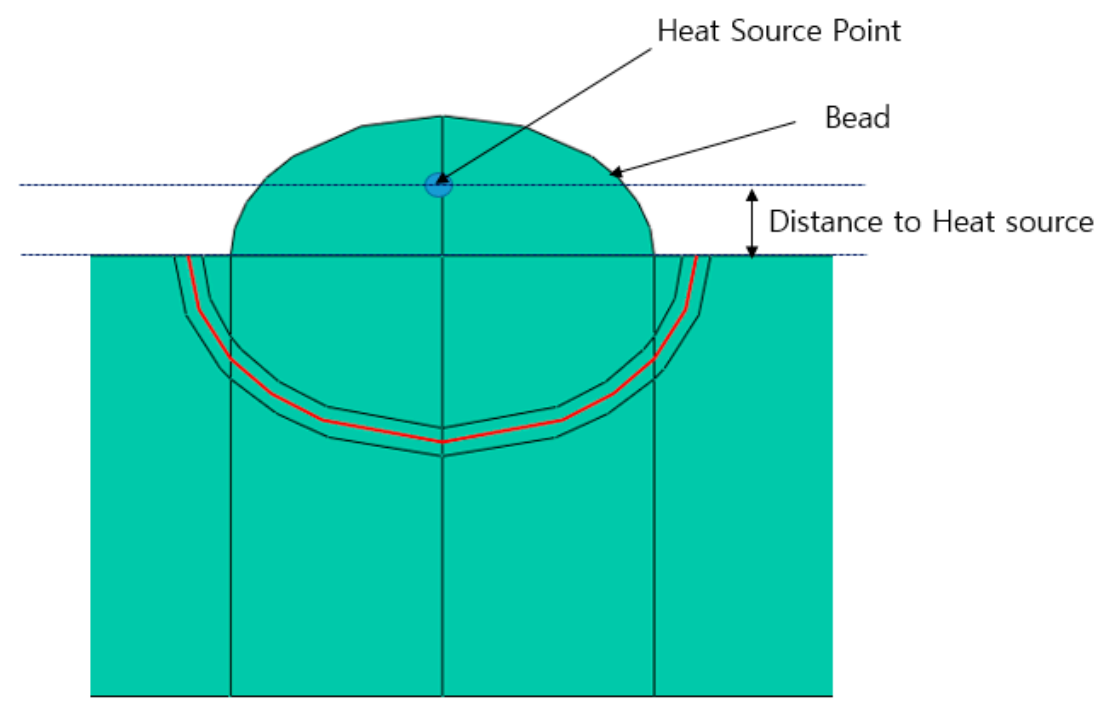

Figure 2. Definition of the heat source point.

\section{Background}

\subsection{Heat Source Model}

This study applied the Goldak model, which is the most commonly used double-ellipsoidal heat source model. The Goldak model is recognized for its high consistency and has been applied to a wide variety of arc welding simulation research, such as SMAW, FCAW, SAW, Plasma Arc Welding (PAW), and GMAW [9-15]. 


\subsection{Global Optimization Algorithm}

A genetic algorithm is an optimization algorithm that simulates natural selection and the genetic process of living organisms. Most species select and cross genes that adapt well to a given environment to pass on superior genes to the next generation, and sometimes, mutation is used to pass on superior genes to later generations. This evolution continues through generations, leaving only the superior genes. A genetic algorithm is an optimization algorithm simulating this process, which can be applied to all optimization problems and is also effective in global optimization [28].

Figure 3 shows the flow of a genetic algorithm, where the process of initial population generation-selection-crossover-mutation-acceptance of the new generation-replacement of the new generation is repeated. Individuals are variables for optimization, and a solution is found by using a combination of individuals. New combinations are created based on the results of various combinations, in which new combinations are formed through crossover and mutation. Additionally, this solution is compared with the previous solution and is either adopted if there are improvements or is rejected if there are no improvements. The process continues through generations, and the population evolves until they find the target solution.

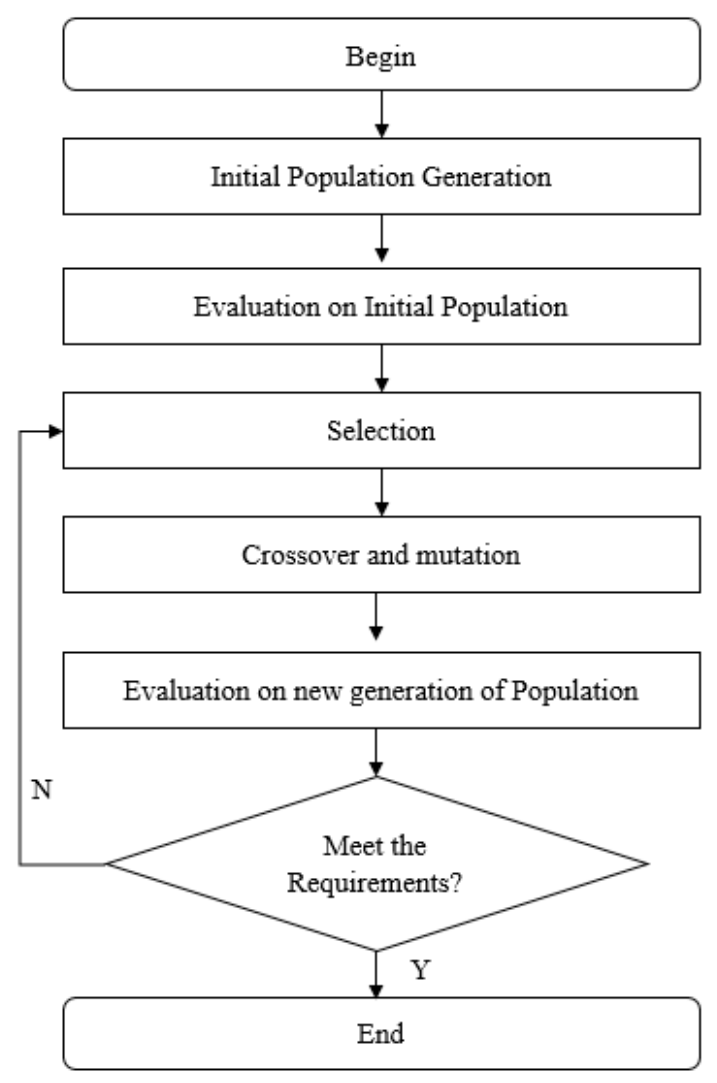

Figure 3. Genetic algorithm flow [15].

This study applied a multi-island genetic algorithm, which is an improved genetic algorithm. A multi-island genetic algorithm divides each population of individuals into several sub-groups called islands. The major difference is that conventional genetic algorithms are carried out in one group without sub-groups. In a multi-island genetic algorithm, all genetic operations are performed separately on each island, and migration occurs periodically from one generation to another. Figure 4 below shows the respective process. 


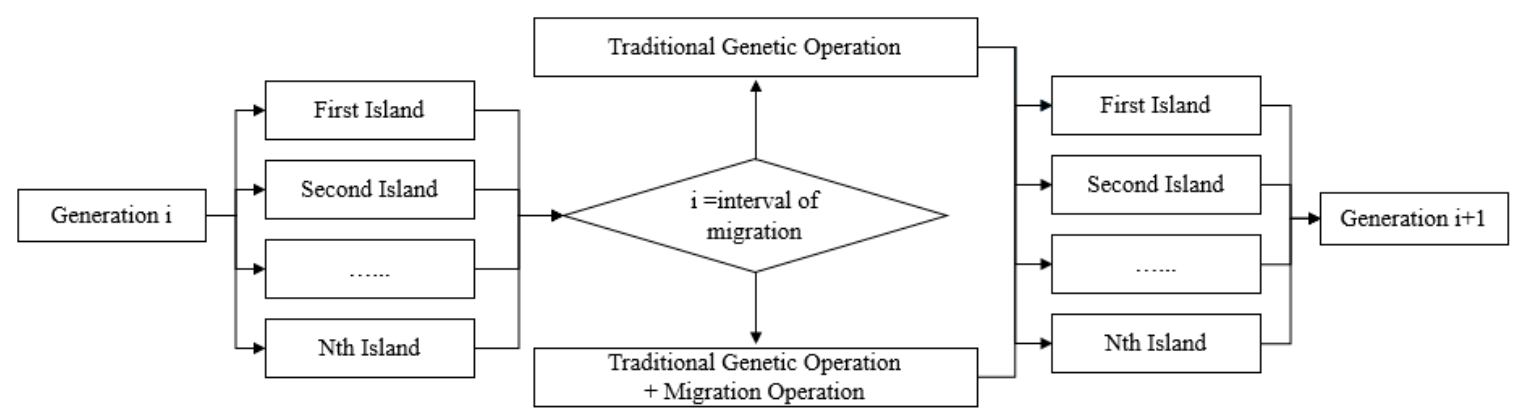

Figure 4. Process of multi-island genetic algorithm flow [15].

Genetic algorithms are widely used for design optimization in the aviation and electronics industries, and are also used in some areas of research related to welding [15-18].

\section{Experiment}

\subsection{Experiment Setup}

This study used SS400 plates $(200 \mathrm{~mm} \times 80 \mathrm{~mm} \times 15.6 \mathrm{~mm})$ as the base metal to confirm the BOP. The same material with a diameter of $1.2 \mathrm{~mm}$ was used as the filler metal, and surface treatment was performed with a stainless wire brush and sand paper (\#300) to ensure high welding quality. Tables 1 and 2 below show the properties and the chemical composition of the welding materials.

Table 1. Mechanical properties of the base metal and filler metal used.

\begin{tabular}{cccccc}
\hline Type & Material & $\begin{array}{c}\text { TS } \\
(\mathbf{M P a})\end{array}$ & $\begin{array}{c}\text { YS } \\
\mathbf{( M P a )}\end{array}$ & $\begin{array}{c}\text { Elongation } \\
\mathbf{( \% )}\end{array}$ & $\begin{array}{c}\text { Hardness } \\
\mathbf{( H V )}\end{array}$ \\
\hline Base metal & SS400 & 435 & 325 & 25 & 128 \\
\hline Filler metal & AWS A5.29 & 550 & 470 & 19 & - \\
\hline
\end{tabular}

Table 2. Chemical composition of the base metal and filler metal used.

\begin{tabular}{ccccc}
\hline Material & \multicolumn{5}{c}{ Composition (\%) } \\
\hline \multirow{3}{*}{ SS400 } & $\mathrm{C}$ & $\mathrm{Si}$ & $\mathrm{Mn}$ & $\mathrm{P}$ \\
\cline { 2 - 5 } & 0.15 & 0.05 & 0.697 & 0.113 \\
\cline { 2 - 5 } & $\mathrm{S}$ & $\mathrm{Cu}$ & $\mathrm{Cr}$ & $\mathrm{Ni}$ \\
\cline { 2 - 5 } & 0.007 & 0.041 & 0.087 & 0.503 \\
\hline \multirow{2}{*}{ AWS A5.29 } & $\mathrm{C}$ & $\mathrm{Si}$ & $\mathrm{Mn}$ & $\mathrm{P}$ \\
\cline { 2 - 5 } & 0.03 & 0.47 & 1.41 & 0.007 \\
\cline { 2 - 5 } & $\mathrm{S}$ & $\mathrm{Cu}$ & $\mathrm{Cr}$ & $\mathrm{Ni}$ \\
\cline { 2 - 5 } & 0.005 & - & 0.02 & 1.4 \\
\hline
\end{tabular}

As shown in Figure 5, a welding system with a robot (Samsung, Suwon, Korea) was used for the experiment, by using the backhand welding technique and applying $\mathrm{CO}_{2}$ as the shielding gas [29]. 


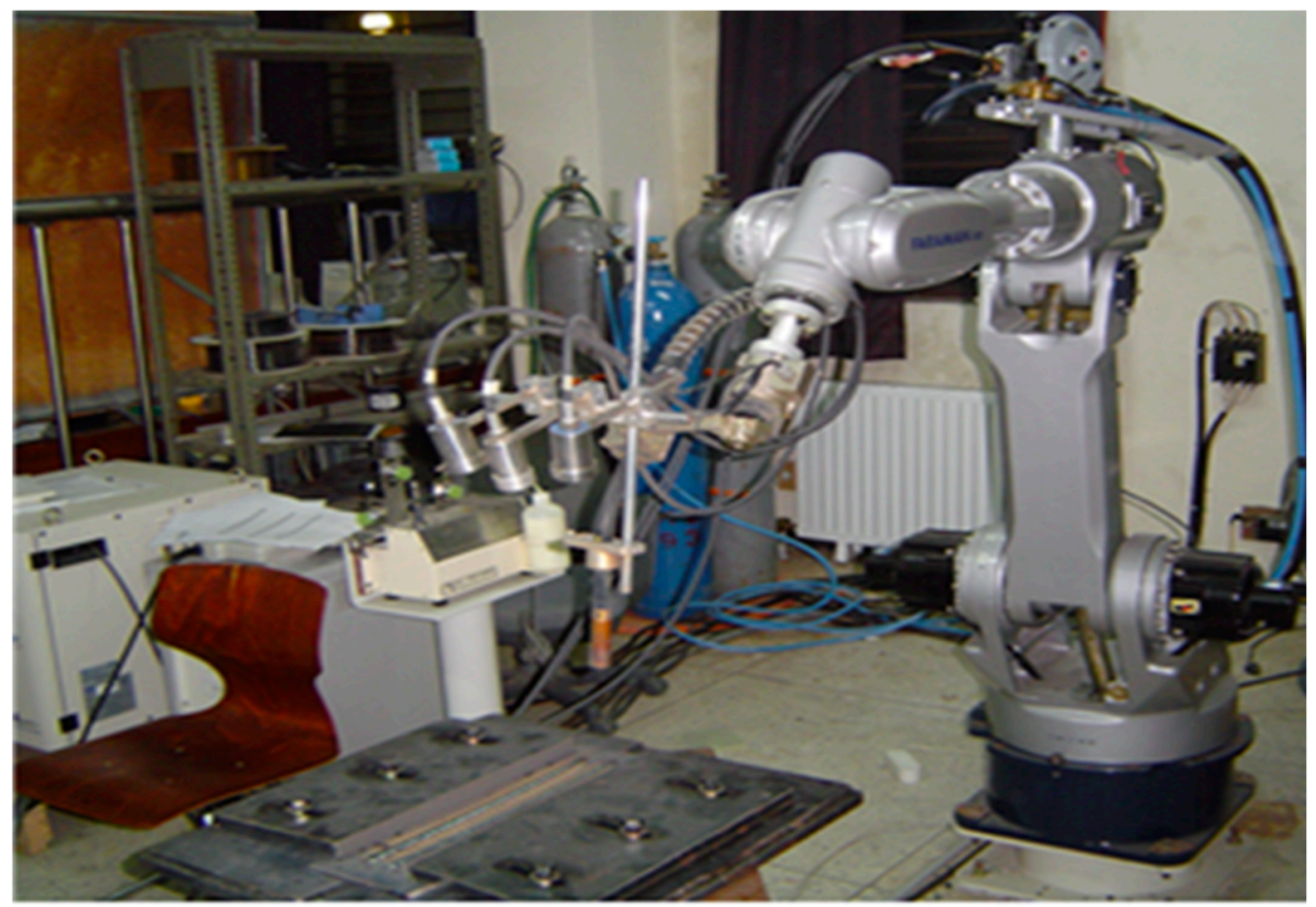

Figure 5. Welding system for the experiment.

\subsection{Experiment Condition}

The main welding conditions were: current (200 A), voltage (24 V), and shielding gas flow rate (18 $\ell / \mathrm{min}$ ). The CTWD (Contact Tip to Work Distance) was $21 \mathrm{~mm}$ and the wire feeding rate was fixed to 10 CPM (Centimeter Per Minute; Table 3).

Table 3. Welding parameters.

\begin{tabular}{cccc}
\hline Parameter & Value & Parameter & Value \\
\hline Current & $200 \mathrm{~A}$ & Shielding gas flow rate & $18 \ell / \mathrm{min}$ \\
\hline Voltage & $24 \mathrm{~V}$ & Welding speed & $100 \mathrm{~mm} / \mathrm{min}$ \\
\hline Wire Feeding rate & $100 \mathrm{~mm} / \mathrm{min}$ & & \\
\hline
\end{tabular}

\subsection{Experiment Result and Data Measurement}

After the welding experiment, the center of the specimen was cut to a size of $40 \mathrm{~mm} \times 20 \mathrm{~mm}$ with a wire cutting machine to observe the dimensions of the HAZ. Polishing was performed using $3 \%$ $\mathrm{HNO}_{3}$ and $\mathrm{H}_{2} \mathrm{O}$ Nital solution, and an optical microscope system was used for a precise measurement. Based on the image, the required data were extracted by coordinating the bead size and the boundary of the HAZ as shown in Figure 6 and Table 4. The bead size was measured to be $W=15.02 \mathrm{~mm}$, $\mathrm{H}=4.96 \mathrm{~mm}$. 


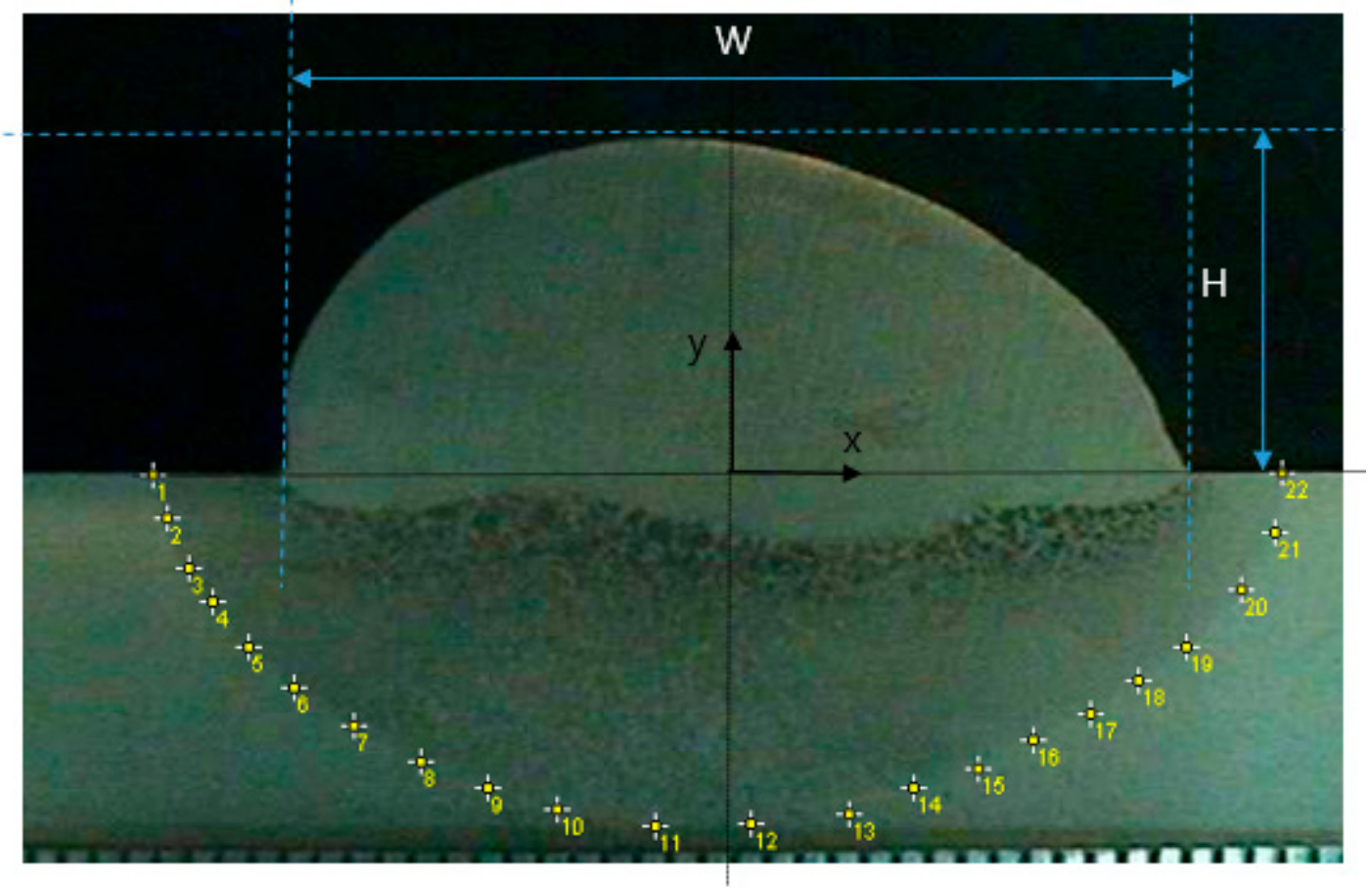

Figure 6. Weld bead and Heat Affected Zone (HAZ) geometry.

Table 4. HAZ boundary coordinates.

\begin{tabular}{cccccc}
\hline $\begin{array}{c}\text { HAZ } \\
\text { Boundary }\end{array}$ & X-coordinate & Y-coordinate & $\begin{array}{c}\text { HAZ } \\
\text { Boundary }\end{array}$ & X-coordinate & Y-coordinate \\
\hline Point 1 & -9.0 & 0.0 & Point 12 & 0.1 & -6.5 \\
\hline Point 2 & -8.8 & -0.9 & Point 13 & 1.4 & -6.5 \\
\hline Point 3 & -8.4 & -1.7 & Point 14 & 2.5 & -6.0 \\
\hline Point 4 & -8.1 & -2.5 & Point 15 & 3.7 & -5.5 \\
\hline Point 5 & -7.6 & -3.3 & Point 16 & 4.6 & -5.1 \\
\hline Point 6 & -6.8 & -4.0 & Point 17 & 5.6 & -4.6 \\
\hline Point 7 & -6.0 & -4.9 & Point 18 & 6.6 & -3.9 \\
\hline Point 8 & -4.8 & -5.4 & Point 19 & 7.3 & -3.3 \\
\hline Point 9 & -3.9 & -6.0 & Point 20 & 8.0 & -2.0 \\
\hline Point 10 & -3.0 & -6.2 & Point 21 & 8.4 & -1.1 \\
\hline Point 11 & -1.1 & -6.6 & Point 22 & 8.7 & -0.2 \\
\hline
\end{tabular}

\section{Numerical Simulation}

\subsection{FE Simulation}

This study used Abaqus (Ver. 2020, Dassault Systems Simulia Corp, RI, USA) as the FE software and a user subroutine function in Fortran (Ver.17.0, Intel, CA, USA) to simulate the moving heat source. Abaqus and Fortran are used in various studies because their performance has been verified in simulating and analyzing moving heat sources in welding.

The modeling process was performed under the same conditions as the actual experiment, and the bead shape was modeled by referring to the bead shape in the experiment as shown in Figure 7 . Figure 8 shows the material properties of the base metal and the bead, which were derived by using JMatPro. 


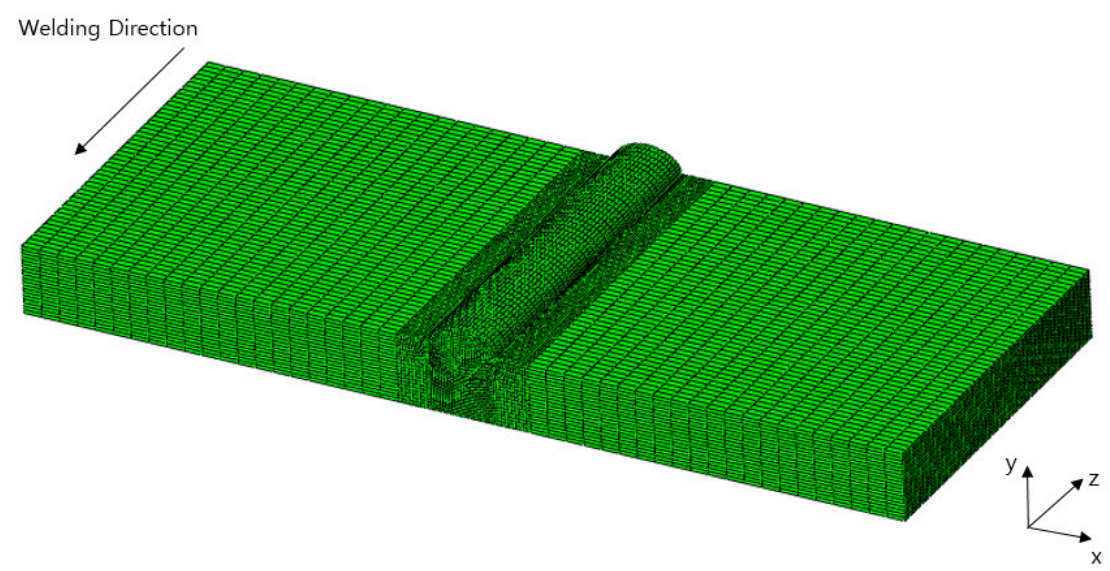

Figure 7. Modeling for FEM analysis applying a moving heat source.
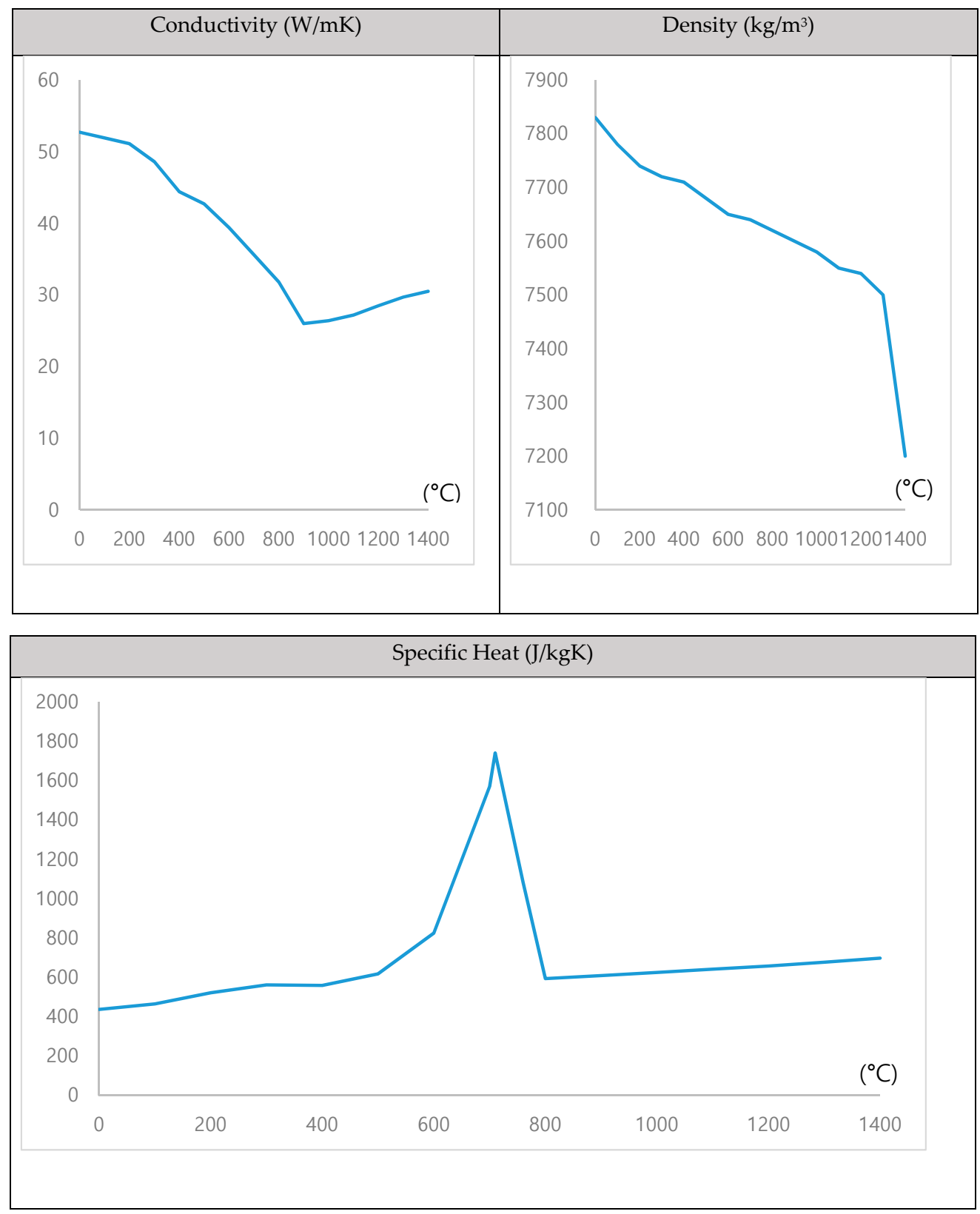

Figure 8. Material property of SS400 by temperature. 
A transient model was used to check the temperature change over time, simulating the heat source moving at a speed of 10 CPM $(1.667 \mathrm{~mm} / \mathrm{s})$ in the Z-direction, which is the same condition as the actual experiment. For a quick analysis, a different mesh size was applied to each area to configure a 3D model composed of a total of 90,000 elements and 100,000 nodes. The 8-node linear heat transfer brick (DC3D8) element was used for this research, the minimum size of the element was $0.8 \mathrm{~mm}$.

The cross-section in the Z-direction was confirmed by analyzing the results, which was $33.333 \mathrm{~mm}$ away from the initial point (20 s after welding). Since the heat source moved at a constant speed, the temperature distribution in each thickness direction was the same with a difference in time after $16.667 \mathrm{~mm}$ (Figure 9). In this welding condition, the edge effect did not have an affect after $16.667 \mathrm{~mm}$.

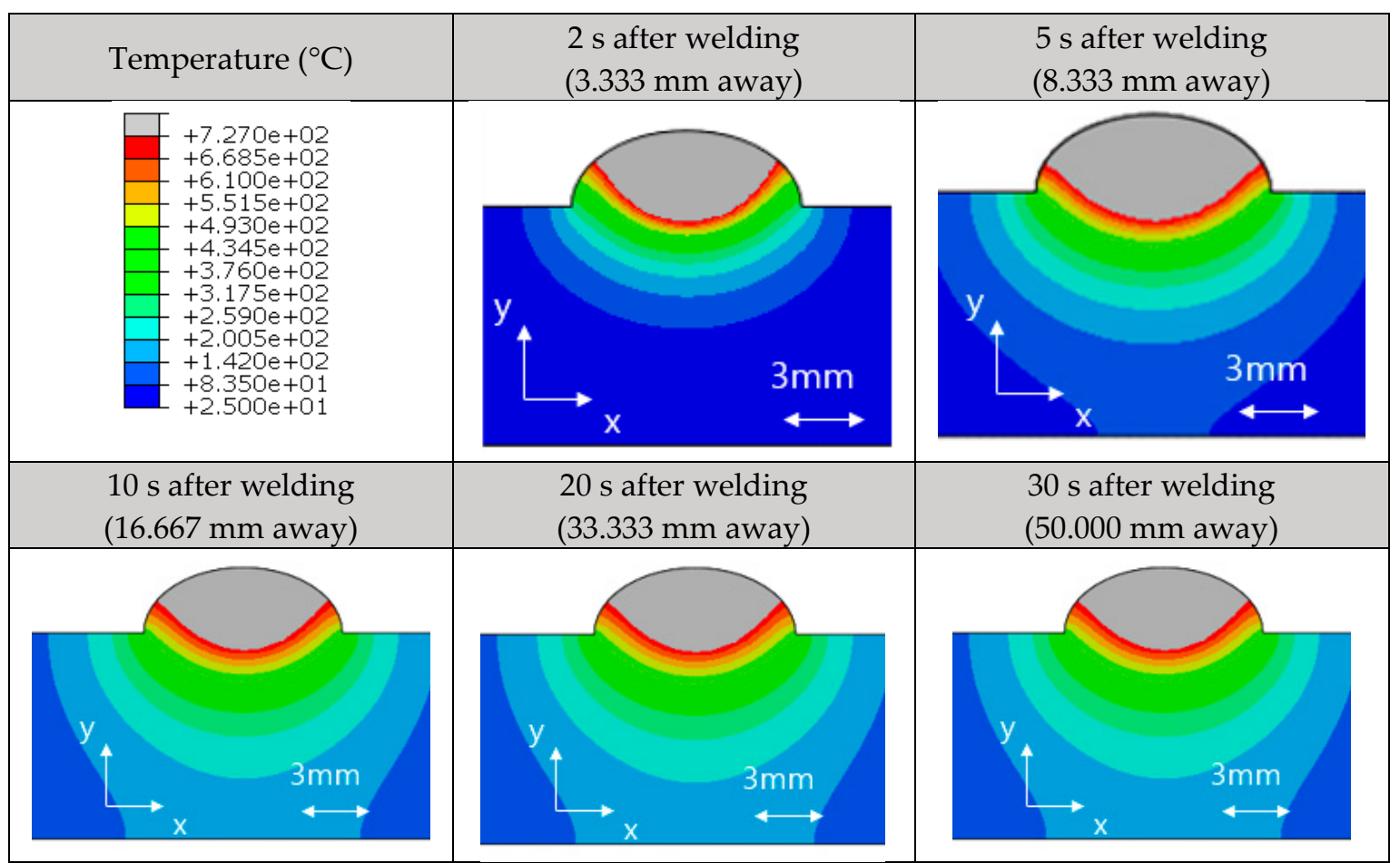

Figure 9. Temperature distribution in the cross-section (under the heat source).

A moving heat source using the Goldak model was applied as the loading condition, and the film coefficients by temperature as the boundary conditions. Equation (6), Equation (7), and Figure 10 show the details of the boundary conditions. The film coefficients were applied to reflect both convective and radiant heat transfer by referring to a related study [12].

$$
\begin{gathered}
H=0.0668 \times \mathrm{T}(\mathrm{T}<500) \\
\mathrm{H}=(\mathrm{T} \times 0.237)-82.1(\mathrm{~T}>500)
\end{gathered}
$$

$\mathrm{H}-$ Film coefficient $\left(\mathrm{W} / \mathrm{m}^{2} \mathrm{~K}\right)$;

$\mathrm{T}$-Temperature $\left({ }^{\circ} \mathrm{C}\right)$. 


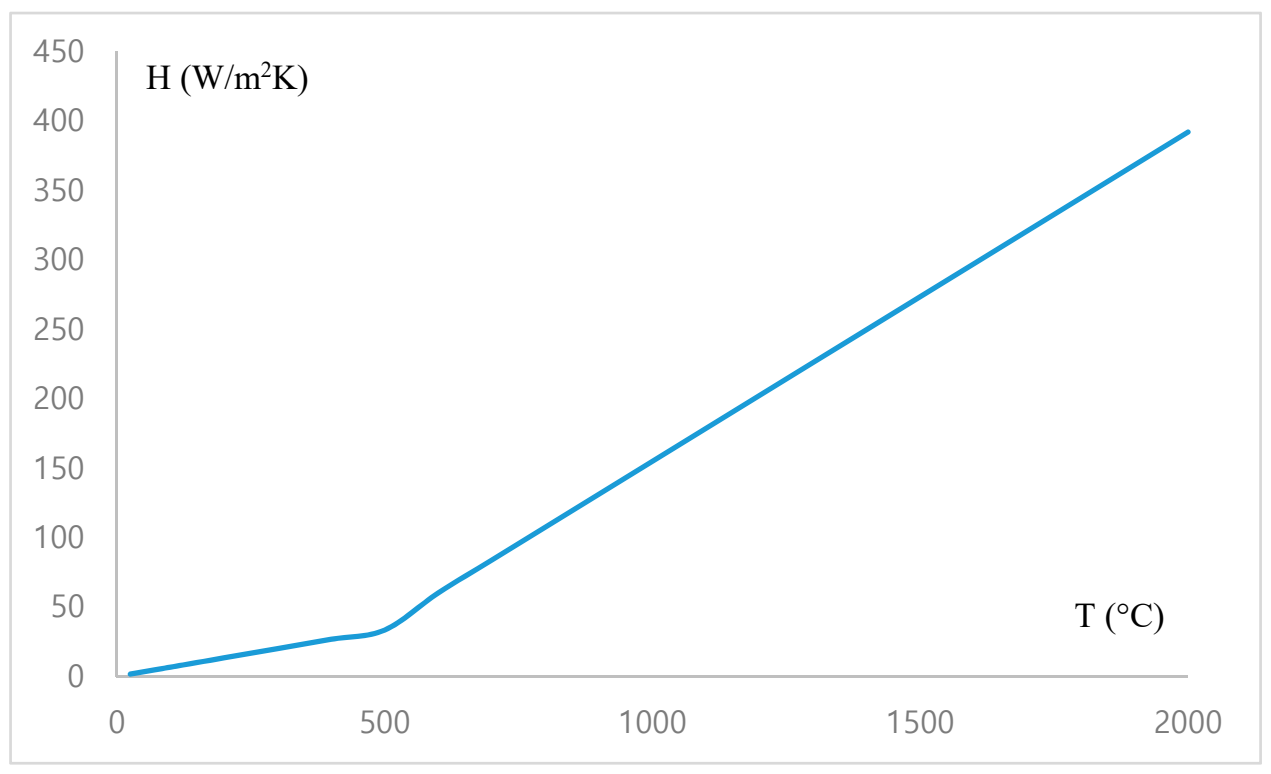

Figure 10. Temperature-dependent film coefficient.

\subsection{Target and Variables}

The HAZ temperature was set as the target to determine the Goldak heat source model, which is the main purpose of this study. Figure 11 shows the results of simulating the HAZ border line of the experimental results, where the temperatures of the five check points were examined on each of the inner line and outer line offset $1 \mathrm{~mm}$ from the HAZ border line. The points on the inner check line should have a temperature distribution of $727^{\circ} \mathrm{C}$ or higher during the welding process, and the points on the outer check line a temperature distribution of $727^{\circ} \mathrm{C}$ or lower. The above criteria were set as the target.

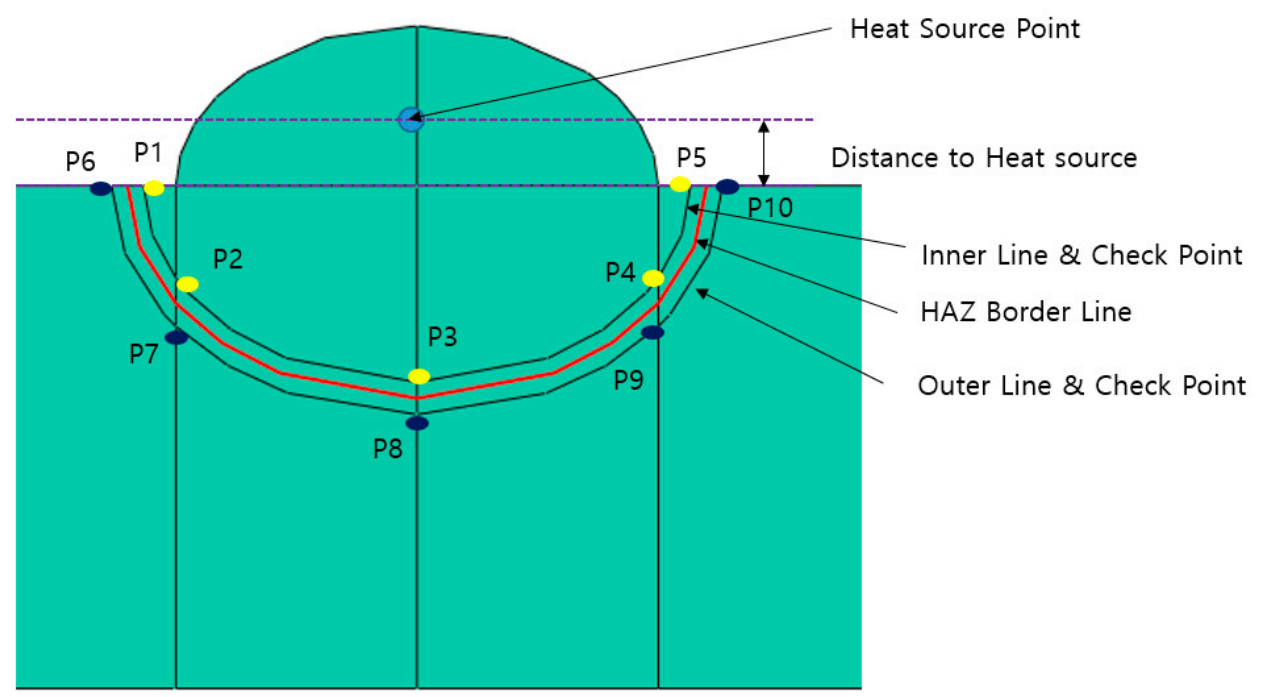

Figure 11. HAZ border line and temperature check line.

A total of six variables were selected to achieve the target including the main variables of the Goldak model $\left(\mathrm{a}_{\mathrm{f}}, \mathrm{a}_{\mathrm{r}} / \mathrm{a}_{\mathrm{f}}, \mathrm{b}, \mathrm{c}\right)$, weld efficiency, and the location of the heat source point.

Most previous studies fixed the relationship between $\mathrm{a}_{\mathrm{r}}$ and $\mathrm{a}_{\mathrm{f}}$, which varied between the range of 3-5 depending on each study [18,30-32]. This study, however, sets this relationship as a variable

Table 5 defines the range of the main variables, which were defined as widely as possible to find the appropriate values. 
Table 5. Variables and range.

\begin{tabular}{ccc}
\hline Variables & Lower Bound & Upper Bound \\
\hline $\mathrm{a}_{\mathrm{f}}$ & $1.0 \mathrm{~mm}$ & $6.0 \mathrm{~mm}$ \\
\hline $\mathrm{a}_{\mathrm{r}} / \mathrm{a}_{\mathrm{f}}$ & 2.0 & 7.0 \\
\hline $\mathrm{b}$ & $1.0 \mathrm{~mm}$ & $10.0 \mathrm{~mm}$ \\
\hline $\mathrm{c}$ & $1.0 \mathrm{~mm}$ & $8.0 \mathrm{~mm}$ \\
\hline$\mu$ (weld efficiency) & 0.2 & 0.9 \\
\hline Distance to heat source & $0 \mathrm{~mm}$ & $4.96 \mathrm{~mm}$ \\
\hline
\end{tabular}

\subsection{Algorithm Property}

Table 6 shows the main parameters and details to apply the multi-island genetic algorithm.

Table 6. Parameters of multi-island genetic algorithm.

\begin{tabular}{ccc}
\hline Parameter & Value & Note \\
\hline Sub-population size & 10 & Population by island \\
\hline Number of islands & 10 & Number of islands \\
\hline Number of generations & 10 & Total number of evolved generations \\
\hline Rate of crossover & $100 \%$ & Crossover rate \\
\hline Rate of mutation & $1 \%$ & Mutation rate \\
\hline Rate of migration & $1 \%$ & Island migration rate \\
\hline Interval of migration & 5 & Number of island migration generations \\
\hline
\end{tabular}

\section{Results and Discussion}

Over 1000 models were compared by using the optimal algorithm to find acceptable results. Table 7 shows the list of candidate groups created by the optimal algorithm that meets the conditions wherein the outer line was higher than $727^{\circ} \mathrm{C}$ and the inner line was lower than $727^{\circ} \mathrm{C}$.

Table 7. Optimal value candidates created by the optimal algorithm.

\begin{tabular}{ccccccc}
\hline Candidate & $\boldsymbol{\mu}$ & $\mathbf{a}_{\mathbf{f}}$ & $\mathbf{b}$ & $\mathbf{c}$ & Distance to Heat Source $(\mathbf{m m})$ & $\mathbf{a}_{\mathbf{r}} / \mathbf{a}_{\mathbf{f}}$ \\
\hline $\mathbf{1}$ & 0.47 & 1.90 & 4.02 & 4.72 & 4.47 & 2.41 \\
\hline $\mathbf{2}$ & 0.46 & 1.90 & 4.02 & 4.72 & 4.43 & 2.41 \\
\hline $\mathbf{3}$ & 0.47 & 1.90 & 4.01 & 5.96 & 4.19 & 2.41 \\
\hline $\mathbf{4}$ & 0.42 & 1.28 & 3.82 & 5.79 & 3.66 & 6.83 \\
\hline $\mathbf{5}$ & 0.47 & 1.90 & 4.02 & 4.72 & 4.43 & 2.84 \\
\hline $\mathbf{6}$ & 0.32 & 3.68 & 5.25 & 3.70 & 1.82 & 2.10 \\
\hline $\mathbf{7}$ & 0.47 & 1.90 & 4.02 & 4.72 & 4.43 & 6.59 \\
\hline $\mathbf{8}$ & 0.59 & 5.81 & 5.96 & 4.13 & 0.18 & 5.09 \\
\hline $\mathbf{9}$ & 0.32 & 3.21 & 5.25 & 3.70 & 1.82 & 2.10 \\
\hline $\mathbf{1 0}$ & 0.32 & 3.21 & 5.25 & 3.70 & 1.79 & 2.10 \\
\hline
\end{tabular}


After checking the temperature distribution results of each of the candidate groups above, this study selected the model with a HAZ boundary shape most similar to the actual experimental results. Based on the depth and width of the HAZ boundary, candidate groups similar to the experimental results were searched, and the temperature distribution was checked based on the time when each point reached its maximum temperature. For example, in the case of candidate group 1, the maximum length in the width direction occurred $31 \mathrm{~s}$ after welding (11 s after the heat source), the maximum length in the depth direction occurred $34 \mathrm{~s}$ after welding (14 s after the heat source), and the width after $31 \mathrm{~s}$ was $17.5 \mathrm{~mm}$, and the depth after $34 \mathrm{~s}$ was $6.6 \mathrm{~mm}$. Figure 12 shows the details, Table 8 shows the variables selected through this process, Table 9 shows the HAZ boundary derived from finite element analysis and the actual experimental values, and Table 10 shows the temperature of the check point. The check points are described in Figure 10.

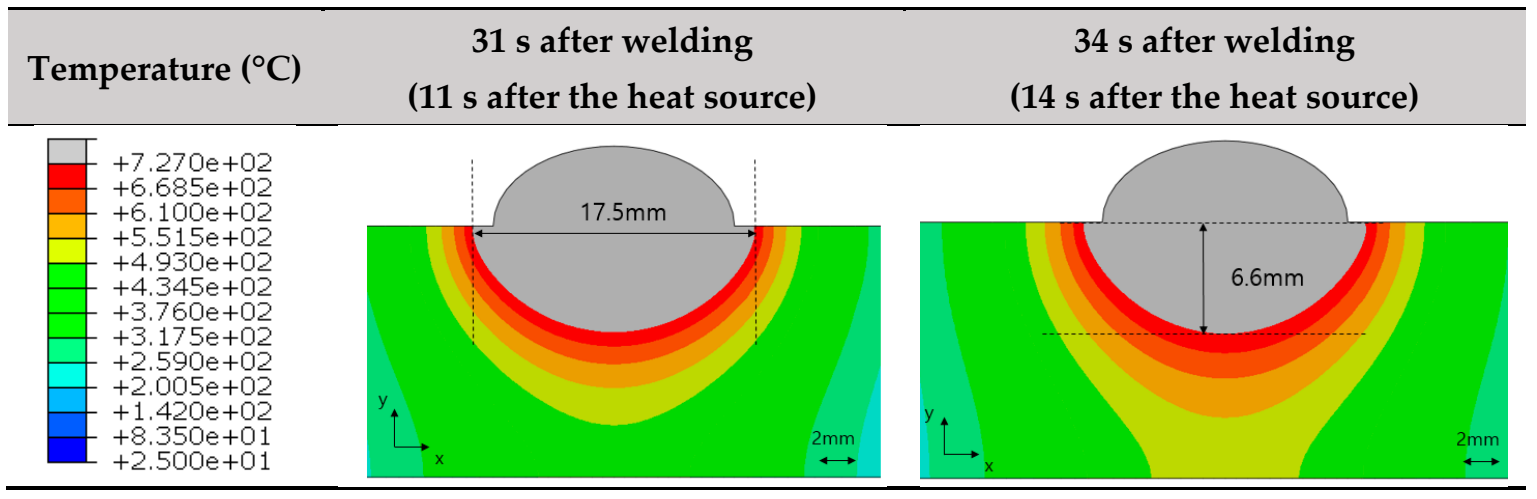

Figure 12. Temperature distribution of FEM.

Table 8. Results of optimization.

\begin{tabular}{cc}
\hline Variables & Values \\
\hline $\mathrm{a}_{\mathrm{f}}$ & $1.9 \mathrm{~mm}$ \\
\hline $\mathrm{a}_{\mathrm{r}} / \mathrm{a}_{\mathrm{f}}$ & 2.41 \\
\hline $\mathrm{b}$ & $4.02 \mathrm{~mm}$ \\
\hline $\mathrm{c}$ & $4.72 \mathrm{~mm}$ \\
\hline$\mu$ (weld efficiency) & 0.47 \\
\hline Distance to heat source & $4.47 \mathrm{~mm}$ (Bead height $=4.96 \mathrm{~mm})$ \\
\hline
\end{tabular}

Table 9. Dimension of HAZ.

\begin{tabular}{ccc}
\hline Dimension of HAZ & Experiment & Result of FEM \\
\hline Width & $17.7 \mathrm{~mm}$ & $17.5 \mathrm{~mm}$ \\
\hline Depth & $6.6 \mathrm{~mm}$ & $6.6 \mathrm{~mm}$ \\
\hline
\end{tabular}


Table 10. Analysis results by measurement location.

\begin{tabular}{ccc}
\hline Point & Value $\left({ }^{\circ} \mathrm{C}\right)$ & Target value $\left({ }^{\circ} \mathrm{C}\right)$ \\
\hline Point 1 $(\mathrm{P} 1)$ & 754.7 & $>727$ \\
\hline Point 2 $(\mathrm{P} 2)$ & 733.8 & $>727$ \\
\hline Point 3 $(\mathrm{P} 3)$ & 768.6 & $>727$ \\
\hline Point 4 $(\mathrm{P} 4)$ & 733.8 & $>727$ \\
\hline Point 5 $(\mathrm{P} 5)$ & 754.7 & $>727$ \\
\hline Point 6 $(\mathrm{P} 6)$ & 651.4 & $<727$ \\
\hline Point 7 $(\mathrm{P} 7)$ & 662.2 & $<727$ \\
\hline Point 8 $(\mathrm{P} 8)$ & 705.9 & $<727$ \\
\hline Point 9 $(\mathrm{P} 9)$ & 662.2 & $<727$ \\
\hline Point 10 $(\mathrm{P} 10)$ & 651.4 & $<727$ \\
\hline
\end{tabular}

Figure 13 shows the temperature distribution according to the time under the optimal conditions, where all of the points reached maximum temperature 30-34 s after welding (10-14 s after the source point; Table 11). This is because of the time required for heat conduction.
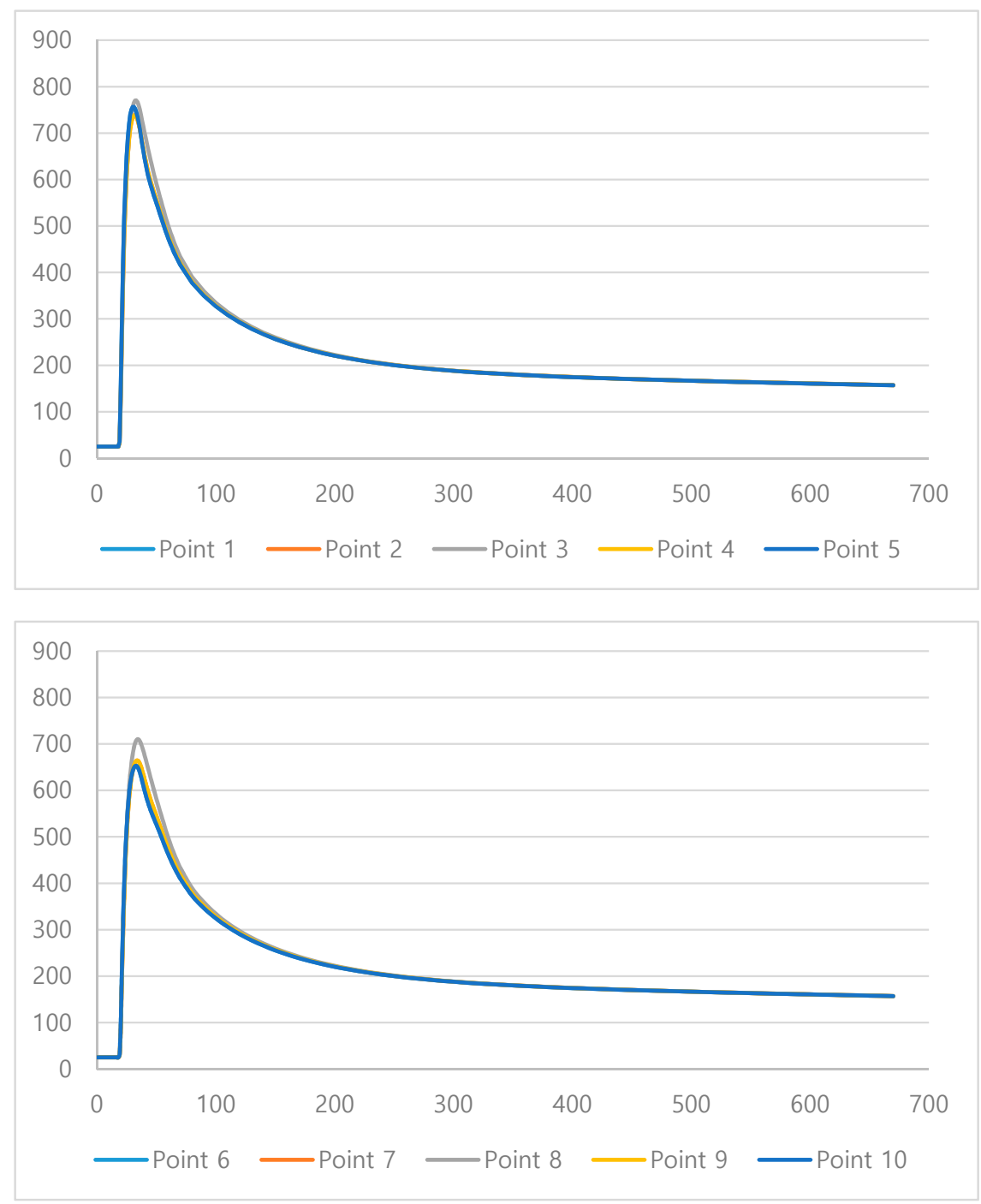

Figure 13. Temperature change over the time on check points. 
Table 11. Temperature change over the time on check points $\left({ }^{\circ} \mathrm{C}\right)$.

\begin{tabular}{ccccccccccc}
\hline Time(s) & P1 & P2 & P3 & P4 & P5 & P6 & P7 & P8 & P9 & P10 \\
\hline & & & & & $\ldots$ & & & & & \\
\hline $\mathbf{2 8}$ & 740.30 & 709.25 & 720.79 & 709.25 & 740.30 & 614.83 & 607.82 & 635.52 & 607.82 & 614.83 \\
\hline $\mathbf{2 9}$ & 751.10 & 724.31 & 741.45 & 724.31 & 751.10 & 630.50 & 627.36 & 659.08 & 627.36 & 630.50 \\
\hline $\mathbf{3 0}$ & $\mathbf{7 5 6 . 3 0}$ & 733.84 & 756.19 & 733.84 & $\mathbf{7 5 6 . 3 0}$ & 641.61 & 642.23 & 677.54 & 642.23 & 641.61 \\
\hline $\mathbf{3 1}$ & $\mathbf{7 5 6 . 1 8}$ & 738.21 & 765.67 & 738.21 & 756.18 & 648.54 & 652.83 & 691.60 & 652.83 & 648.54 \\
\hline $\mathbf{3 2}$ & $\mathbf{7 5 2 . 6 8}$ & $\mathbf{7 3 8 . 7 0}$ & 770.17 & $\mathbf{7 3 8 . 7 0}$ & 752.68 & 652.23 & 659.84 & 701.39 & 659.84 & 652.23 \\
\hline $\mathbf{3 3}$ & $\mathbf{7 4 5 . 7 0}$ & 735.63 & $\mathbf{7 7 0 . 3 7}$ & 735.63 & 745.70 & $\mathbf{6 5 2 . 8 6}$ & 663.58 & 707.34 & 663.58 & $\mathbf{6 5 2 . 8 6}$ \\
\hline $\mathbf{3 4}$ & 735.68 & 729.40 & 767.22 & 729.40 & 735.68 & 650.67 & 664.32 & 710.03 & 664.32 & 650.67 \\
\hline $\mathbf{3 5}$ & 723.51 & 720.31 & 760.57 & 720.31 & 723.51 & 645.99 & 662.26 & 709.53 & 662.26 & 645.99 \\
\hline $\mathbf{3 6}$ & 709.21 & 708.63 & 750.92 & 708.63 & 709.21 & 638.99 & 657.59 & 706.11 & 657.59 & 638.99 \\
\hline $\mathbf{3 7}$ & 693.07 & 694.96 & 739.29 & 694.96 & 693.07 & 630.01 & 650.70 & 700.34 & 650.70 & 630.01 \\
\hline $\mathbf{3 8}$ & 676.73 & 680.67 & 726.85 & 680.67 & 676.73 & 620.09 & 642.38 & 692.99 & 642.38 & 620.09 \\
\hline & & & & & $\ldots$ & & & & & \\
\hline
\end{tabular}

This study examined the main parameters of the Goldak model, weld efficiency, and the location of the heat source. The results showed that the location of the heat source in the Y-direction should be placed on top of the bead as in the case of previous studies, and the $b$ and $c$ values were also confirmed to be similar.

Finding the main parameters of the welding heat source should be a prerequisite in analyzing temperature distribution due to heat transfer and thermal deformations. This study applied a multi-island genetic algorithm (global optimization algorithm) to achieve this purpose and derived significant results.

\section{Conclusions}

This study used a multi-island genetic algorithm (optimization algorithm) to find the parameters of the Goldak heat source model (a welding heat source model), weld efficiency, and the location of the heat source.

1. The temperature distribution was confirmed by the finite element analysis using a moving heat source by simulating a BOP (Bead on Plate) test with SS400 plates.

2. The HAZ boundary of the specimen was coordinated, and the target was determined by analyzing the results at the line offset from the HAZ boundary. The target was set so that the temperature distribution of the inner offset line is $727^{\circ} \mathrm{C}$ or higher and the outer offset line is $727^{\circ} \mathrm{C}$ or lower.

3. The optimal results were derived by using Isight's multi-island algorithm. These results were derived by comparing over 1000 candidate groups by performing non-linear optimization using global optimization techniques.

4. Based on the results of global optimization, the HAZ boundary line was derived through finite element analysis, and was similar to the actual experimental results.

5. Applying a search method using a multi-island algorithm was found to be useful in finding the welding heat source parameters required for welding heat transfer/thermal deformation analysis.

Author Contributions: Conceptualization: C.P.; K.J. (Jaewoong Kim); K.J. (Jisun Kim), Experiment: K.J. (Jisun Kim), Software: C.P., Validation: C.P.; K.J. (Jaewoong Kim); K.J. (Jisun Kim), Paper research: C.P.; K.J. (Jaewoong Kim); K.J. (Jisun Kim), Data analysis: C.P.; K.J. (Jaewoong Kim), Writing-original draft preparation: C.P., Writing-review and editing: K.J. (Jaewoong Kim); K.J. (Jisun Kim), Supervision: K.J. (Jaewoong Kim), Project administration: K.J. (Jaewoong Kim). All authors have read and agreed to the published version of the manuscript. 
Funding: This study has been conducted with the support of the Korea Institute of Industrial Technology as "Study on the Core Element Technology for Smart Mobility (PJA20070)".

Conflicts of Interest: The authors declare no conflict of interest.

\section{References}

1. Jeshvaghani, R.; Harati, E.; Shamanian, M. Effects of surface alloying on microstructure and wear behavior of ductile iron surface-modified with a nickel-based alloy using shielded metal arc welding. Mater. Des. 2011, 32, 1531-1536. [CrossRef]

2. Kannan, T.; Murugan, N. Effect of flux cored arc welding process parameters on duplex stainless steel clad quality. J. Mater. Process. Technol. 2006, 176, 230-239. [CrossRef]

3. Gunaraj, V.; Murugan, N. Application of response surface methodology for predicting weld bead quality in submerged arc welding of pipes. J. Mater. Process. Technol. 1999, 88, 266-275. [CrossRef]

4. $\mathrm{Hu}, \mathrm{J} . ;$ Tsai, H. Heat and mass transfer in gas metal arc welding. Part I: The arc. Int. J. Heat Mass Transf. 2007, 50, 833-846. [CrossRef]

5. Sepe, R.; Armentani, E.; Lamanna, G.; Caputo, F. Evaluation by FEM of the influence of the reheating and post-heating treatments on residual stresses in welding. Key Eng. Mater. 2015, 627, 93-96. [CrossRef]

6. Armentani, E.; Pozzi, A.; Sepe, R. Finite-element simulation of temperature fields and residual tresses in butt welded joints and comparison with experimental measurements. In Proceedings of the ASME 2014 12th Biennial Conference on Engineering Systems Design and Analysis, Copenhagen, Denmark, 25-27 June 2014.

7. Armentani, E.; Esposito, R.; Sepe, R. The influence of thermal properties and preheating on residual stresses in welding. Int. J. Comput. Mater. Sci. Surf. Eng. 2007, 1, 146-162. [CrossRef]

8. Rosenthal, D. The Theory of Moving Sources of Heat and Its Application to Metal Treatments. Trans. Am. Soc. Mech. Eng. 1946, 68, 849-866.

9. Goldak, J.; Chakravarti, A.; Bibby, M. A new finite element model for welding heat sources. MTB 1984, 15, 299-305. [CrossRef]

10. Lee, S.; Kim, E.; Park, J.; Choi, J. MIG Welding Optimization of Muffler Manufacture by Microstructural Change and Thermal Deformation Analysis. J. Weld. Join. 2017, 35, 29-37. [CrossRef]

11. Tchoumi, T.; Peyraut, F.; Bolot, R. Influence of the welding speed on the distortion of thin stainless steel plates-Numerical and experimental investigations in the framework of the food industry machines. $J$. Mater. Process. Technol. 2016, 229, 216-229. [CrossRef]

12. Chujutalli, J.H.; Lourenço, M.I.; Estefen, S.F. Experimental-based methodology for the double ellipsoidal heat source parameters in welding simulations. Mar. Syst. Ocean Technol. 2020, 15, 110-123. [CrossRef]

13. Podder, D.; Mandal, N.R.; Das, S. Heat Source Modeling and Analysis of Submerged Arc Welding. Weld. J. 2014, 93, 183-192.

14. Kim, J.W.; Jang, B.S.; Kim, Y.T.; Chun, K.S. A study on an efficient prediction of welding deformation for T-joint laser welding of sandwich panel PART I: Proposal of a heat source model. Int. J. Nav. Arch. Ocean. 2013, 5, 348-363. [CrossRef]

15. Hu, X.; Chen, X.; Zhao, Y.; Yao, W. Optimization design of satellite separation systems based on Multi-Island Genetic Algorithm. Adv. Space Res. 2014, 53, 870-876. [CrossRef]

16. Lin, B.; Yu, Q.; Li, Z.; Zhou, X. Research on parametric design method for energy efficiency of green building in architectural scheme phase. Front. Archit. Res. 2013, 2, 11-22. [CrossRef]

17. Wang, Z.; Ma, J.; Zhang, L. State-of-Health Estimation for Lithium-Ion Batteries Based on the Multi-Island Genetic Algorithm and the Gaussian Process Regression. IEEE Access 2017, 5, 21286-21295. [CrossRef]

18. Zhao, D.J.; Wang, Y.K.; Cao, W.W.; Zho, P. Optimization of Suction Control on an Airfoil Using Multi-island Genetic Algorithm. Procedia Eng. 2015, 99, 696-702. [CrossRef]

19. Deng, D. FEM prediction of welding residual stress and distortion in carbon steel considering phase transformation effects. Mater. Des. 2009, 30, 359-366. [CrossRef]

20. Narang, H.K.; Mahapatra, M.M.; Jha, P.K.; Sridhar, P.; Biswas, P. Experimental and Numerical Study on Effect of Weld Reinforcement on Angular Distortion of SAW Square Butt Welded Plates. J. Weld. Join. 2018, 36, 48-59. [CrossRef]

21. Moradi, M.; Pasternak, H. A Study on the Influence of Various Welding Sequence Schemes on the Gain in Strength of Square Hollow Section Steel T-Joint. J. Weld. Join. 2017, 35, 41-50. [CrossRef] 
22. El-Sayed, M.; Shash, A.Y.; Rabou, M. Heat Transfer Simulation and Effect of Tool Pin Profile and Rotational Speed on Mechanical Properties of Friction Stir Welded AA5083-O. J. Weld. Join. 2017, 35, 35-43. [CrossRef]

23. Wang, W.; Mo, R.; Zhang, Y. Multi-Objective Aerodynamic Optimization Design Method of Compressor Rotor Based on Isight. Procedia Eng. 2011, 15, 3699-3703. [CrossRef]

24. Hahn, Y.; Cofer, J. Design Study of Dovetail Geometries of Turbine Blades Using Abaqus and Isight. In Proceedings of the ASME Turbo Expo 2012: Turbine Technical Conference and Exposition, Copenhagen, Denmark, 11-15 June 2012; Volume 7, pp. 11-20.

25. Koch, P.; Evans, J.; Powell, D. Interdigitation for effective design space exploration using iSIGHT. Struct. Multidisc. Optim. 2002, 23, 111-126. [CrossRef]

26. Layus, P.; Kah, P.; Khlusova, E.; Orlov, V. Study of the sensitivity of high-strength cold-resistant shipbuilding steels to thermal cycle of arc welding. Int. J. Mech. Mater. Eng. 2018, 13, 3. [CrossRef]

27. Fu, G.; Lourenço, M.; Duan, M.; Estefen, S. Influence of the welding sequence on residual stress and distortion of fillet welded structures. Mar. Struct. 2016, 46, 30-55. [CrossRef]

28. McKay, B. Evolutionary Algorithms. Encycl. Ecol. 2008, 1464-1472.

29. Kim, J.; Kim, I.; Kim, Y. Optimization of weld pitch on overlay welding using mathematical method. Int. J. Precis. Eng. Manuf. 2014, 15, 1117-1124. [CrossRef]

30. Pozo, L.P.; Olivares, F.; Durán, O. Optimization of welding parameters using a genetic algorithm: A robotic arm-assisted implementation for recovery of Pelton turbine blades. Adv. Mech. Eng. 2015, 7, 1687814015617669. [CrossRef]

31. Gery, D.; Long, H.; Maropoulos, P. Effects of welding speed, energy input and heat source distribution on temperature variations in butt joint welding. J. Mater. Process. Technol. 2005, 167, 393-401. [CrossRef]

32. Reda, R.; Magdy, M.; Rady, M. Ti-6Al-4V TIG Weld Analysis Using FEM Simulation and Experimental Characterization. Iran. J. Sci. Technol. Trans. Mech. Eng. 2019, 44, 765-782. [CrossRef]

(C) 2020 by the authors. Licensee MDPI, Basel, Switzerland. This article is an open access article distributed under the terms and conditions of the Creative Commons Attribution (CC BY) license (http://creativecommons.org/licenses/by/4.0/). 